\author{
Baadzhy N. A., \\ Lecturer at the Department of Foreign Language Competence \\ Odessa State University of Internal Affairs
}

\author{
Chychian O. O., \\ Lecturer at the Department of Foreign Language Competence \\ Odessa State University of Internal Affairs
}

\title{
WRITING A SCIENTIFIC ARTICLE LIKE A NATIVE ENGLISH SPEAKER: USEFUL TIPS FOR UKRAINIAN AUTHORS
}

\begin{abstract}
Summary. The article is devoted to the problem of writing a scientific article in English for Ukrainian-speaking academics and researchers. It gives a clearer understanding for Ukrainian scientists of the key linguistic mistakes authors usually make while writing a scientific article, as well as the ways of avoiding these mistakes.

Conducting scientific research the non-English-speaking authors are supposed to be comprehensible and persuasive in the clarity of their language. In order for the results of research to be accessible to other professionals and have a potential effect on the greater scientific community, the scientific research must be explicitly written and published. Barriers to effective writing include lack of experience, poor writing habits, and unfamiliarity with the requirements of scholarly writing in English, lack of confidence in writing ability, fear of failure, and resistance to feedback.
\end{abstract}

Having an understanding of the scientific language and structure used to produce a peer reviewed publication will surely improve the likelihood that a submitted manuscript will result in a successful publication.

Such an effort can be maximized by following a few simple suggestions when composing/creating the product for submission. By following some suggested guidelines and avoiding common errors, the process can be streamlined and success realized for even beginning/novice authors as they negotiate the publication process. The purpose of this invited commentary is to offer practical suggestions for achieving success when writing and submitting manuscripts to professional peer-reviewed journals.

Writing a scientific article for publication can be a challenging yet satisfying undertaking. The ability to examine, relate, and interlink evidence, as well as to provide a peer reviewed, dispersed product of your research labors can be rewarding. A few suggestions have been offered in this commentary that may assist the novice or the developing writer to attempt, polish, and perfect their approach to scholarly writing.

Key words: tenses, scientific language, scientific research, scientific writing, article.

Successful production of a written product for submission to a peer reviewed scientific journal requires substantial effort. Since nowadays English dominates the world of science. According to various sources up to $96 \%$ of the world's academic literature is published in English. The number of English-language articles as indexed by the Scopus abstracts database is higher than the number of publications in all other national languages combined.
Problem statement. There is no reason to doubt that the proportion of English-language journals will continue to grow and unfortunately as they do so, displace the periodicals published in national languages. Successful production of a written product requires from researchers substantial effort.

The main goal of the article is to give some practical suggestions in achieving success when writing and submitting manuscripts to scientific journals. By following some suggested guidelines and avoiding common mistakes, the result paper can be competitive for English-speaking world and success realized for even beginning authors.

The research papers has passed a long historical way from scientific journals that were the mean of sharing knowledge, discoveries and inventions among the scientists to strictly structured articles with clear logical presentation of information in a form of experimental report. It was purely descriptive, and events were often presented in chronological order [4]. Later on this pre-article evolved to a more structured form in which methods and results were incipiently described and interpreted [1].

Method of description increasingly developed during the second half of the nineteenth century, and an overall organization known as "theory-experiment-discussion" appeared [1].

Method of description increasingly developed during the second half of the nineteenth century, and an overall organization known as "theory-experiment-discussion" appeared [1]. In the early twentieth century, contemporary norms began to be standardized with a decreasing use of the literary style. Gradually, in the course of the twentieth century, the formal established introduction, methods, results, and discussion (IMRaD) structure was adopted.

The logic of IMRAD can be defined in question form: What question (problem) was studied? The answer is the Introduction. How was the problem studied? The answer is the Methods. What were the findings? The answer is the Results. What do these findings mean? The answer is the Discussion [2, p. 7].

The truth is, just like it is one thing to write in Ukrainian and another to write well in Ukrainian, the same applies to writing well in English. Furthermore, not every native English speaker who writes well in English can write well for the scientific literature. Scientific English writing has its own style and rhythm.

The key characteristic of scientific writing is clarity. Successful scientific experimentation is the result of a clear mind attacking a clearly stated problem and producing clearly stated conclusions. In addition to organization, the second principal 
ingredient of a scientific paper should be appropriate language. But at the same time English need not be difficult. The idea is to relate the sense in the fewest short words. Literary devices, metaphors and the like, divert attention from the substance to the style. [2, p. 1-2]. Translating articles from Ukrainian to English brings us to the problem of direct translation of the ideas stated in the article. Thus we omit the principle of clarity and simplicity. Ukrainian language is abundant with various literary devices that simply impossible to translate into English.

Also watch for misuse of words such as: "young juveniles" or "authentic replicas". If there is any expression that is dumber than "7 a.m. in the morning" it is "viable alternative" (If an alternative is not viable, it is not an alternative). This principle is applicable both in English and Ukrainian.

Certain words are wrongly used thousands of times in scientific writing. Some of the worst offenders are the following:

like. Often used incorrectly as a conjunction. Should be used only as a preposition. When a conjunction is needed, substitute "as" Like I just said, this sentence should have started with "As"

amount. Use this word when you refer to a mass or aggregate. Use number when units are involved. "An amount of cash" is all right. "An amount of coins" is wrong.

case. This is the most common word in the language of jargon. Better and shorter usage should be substituted: "in this case" means "here"; "in most cases" means "usually"; "in all cases" means "always"; "in no case" means "never".

\section{Proper Choice of Tense?}

In the typical paper, you will normally go back and forth between the past and present tenses. Abstract should be in the past tense, when you are referring to your own present results. Likewise, the Materials and Methods and the Results sections should be in the past tense, as you describe what you did and what you found. On the other hand, much of the Introduction and much of the Discussion should be in the present tense, because these sections often emphasize previously established knowledge [2; p. 3].

Some researchers think that Passive voice is considered poor English. It is poor indeed but in any form of writing (news, novels, blogs, etc.) outside of science. The most recent version of Microsoft Office Word will even highlight passive voice as poor grammar and ask you if you want to rephrase. However, the use of passive voice is acceptable and even encouraged in some scientific writing.

There are also some mistakes in writing that not always refer to incorrect English, but rather to poor English, and they are not necessarily absolute rules. Most of these are common mistakes or poor writing habits affect even native English speakers, so correcting them before submitting your manuscript can give you an advantage with the reviewers. It may even help you to avoid the dreaded "needs to be reviewed by a native English speaker".

Avoid beginning sentences with "It is...".

In Ukrainian, phrases meant to give emphasis commonly begin as:

“Важсливо, що...”, “Також вважається...”, “Мало / багато уваги приділяється..."

Many people directly translate these phrases as:

"It is important...", "Also, it is considered...", "There is littlel much attention..."

Although these sentences are grammatically correct, they are weak and somewhat juvenile in structure. One or two per section may be fine, but repeatedly using this sentence structure can diminish the perceived maturity of your work.

These phrases can almost always be strengthened by rephrasing (or even directly reversing):

Example 1:

Ukrainian: "Важливо відмітити сучасні наукові праці..."

Weak English: "It is important to highlight the most recent scientific works that..."

Strong English: "The most recent works that (...) are important to highlight."

Example 2:

Ukrainian: "Мало уваги приділяється ...."

Weak English: "There is little attention given to ..."

Strong English: "Little attention is given to ..."

Learn when to use "the"; try to remove it from the beginning of the sentence and to only include it when referring to specific events/objects/people.

The sentence in Ukrainian beginning with: «Положення закону України про адміністративні порушення передбачає...»

Which means the English translation would be:

"The provisions of the Law of Ukraine on Administrative Offences..."

Specifically for scientific writing, "the" can be removed to sound more professional.

"Provisions of the Law of Ukraine on Administrative Offences..."

Remove "that"!

This is a very common style issue made by native English speakers and is a quick way to not only write in English but also to write well in English. "That" should only be used at the beginning of a dependent clause or when describing a subject/noun:

"Результати досліджень демонструють, щзо багато людей порушують закон”.

Directly translated, Ukrainian speakers normally feel more comfortable leaving the word "that" in the sentence. Even some editors add "that" after it was "omitted".

"The results demonstrate that many people break law."

If you remove the "that", the meaning of the phrase does not change, and the phrase is not broken by a breath when you read the sentence aloud:

"The results demonstrate many people break law."

Read both aloud. Can you hear how "that" can break up a sentence and not flow as nicely?

Here are some words that are frequently used in the scientific literature that commonly do not need to be followed by "that":

Suggest or suggested (запропоновано)

Observed (cnocmepizaєmься)

Found or was found (було виявлено)

Show or shown (було вказано)

Is important (важливо, що)

Highlight (підкреслено/наголошено)

Attempt to place adjectives, including possessive adjectives, in front of nouns when possible (adjective-noun rather than noun-"of"adjective). You may need to remove the "s" from a plural adjective.

"Характеристики закону":

"Law characteristics" instead of "characteristics of law"

"Думка автора":

"Author's opinion" instead of "opinion of the author".

An extra note on the usage of "of", here is another very common mistake: 
"У 2010 мало місие 8.8 мільйонів нових справ по даному виду правопорушення у всьому світі.”

Incorrect: "In 2010 there were 8.8 millions of new cases on this offence around the world."

Incorrect: "In 2010, there were 8.8 millions new cases on this offence around the world."

Correct: "In 2010, there were 8.8 million new cases on this offence around the world."

In Ukrainian, it is common to use an "assumed" subject if you have already mentioned the topic in the previous sentence; however, in English, you need to continue to explain what you are referring to throughout the phrase.

"В даному дослідженні включено 74 правопорушника. Серед них 7 (9.5\%) були жінки”.

Directly translated:

"The study includes 74 offenders. Of them 7 (9.5\%) were female".

However, it is important to restate your subject. The importance of this practice will become more apparent in longer, more descriptive phrases. Otherwise, in English, it sometimes becomes difficult to tell which subject you are referring to in the subsequent phrase.

"The study includes 74 patients. Of them, 7 (9.5\%) offenders were female".

Remember, it is more important to be parallel when writing in English than to not be repetitive.

What about punctuation?

Prepositional phrases, transitions and adverbs in the beginning of sentences should be followed by a comma:

However,

Therefore,

Currently

As previously reported,

Try to read the phrase aloud. If you take a breath or pause when reading the sentence, then you likely need a comma there. If a sentence contains more than two commas (not including lists), it should be split into more than one sentence.

Writing for publication can be a challenging yet satisfying endeavor. The ability to examine, relate, and interlink evidence, as well as to provide a peer reviewed, structured product of your research labors can be rewarding. A few suggestions have been offered that may assist the novice or the developing writer to attempt, polish, and perfect their approach to scholarly writing.

Above all, remember that the underlying principle in scientific writing in English is "less is more". This concept varies greatly from the principle underlying most formal Ukrainian writing, in which you must be elaborate to be understood. Consider preparing an outline before you begin writing, and try to avoid deviating from it. An outline will help you to be more objective and rational about the Who, What, When, Why and How of your research, which will be reflected in the quality of your work in English. Even if an idea is related to the topic of your research, if the idea does not add to the rationale of why you conducted the study or why you obtained your results, cut it out. Another strategy is to find a similar paper from the same journal to which you will submit your manuscript and try to mimic its style, structure and content.

\section{References:}

1. Atkinson D. Scientific discourse in sociohistorical context: the Philosophical Transactions of the Royal Society of London, 1675-1975. Mahwah, NJ: Lawrence Erlbaum, 1999;

2. Day RA. How to write \& publish a scientific paper. 5th ed. Phoenix, AZ: Oryx, 1998;

3. Eriksson P, Altermann W, Catuneanu O. Editorial: Some general advice for writing a scientific paper. J African Earth Sci. 2005;

4. Kronick D. A history of scientific and technical periodicals: the origins and development of the scientific and technical press 1665-1790. 2nd ed. Metuchen, NJ: Scarecrow, 1976;

5. Pierson DJ. The top 10 reasons why manuscripts are not accepted for publication. Respir Care. 2004;

6. Robert C. Manske, Barbara J. Hoogenboom. How to write a scientific article: Int. J Sports Phys Ther. 2012 Oct; 7(5): 512-517.

Бааджи Н. А., Чичян О. О. Щодо написання наукової статті як від носія англійської мови: корисні поради для україномовних авторів

Анотація. Стаття присвячена проблемі написання наукової статті англійською мовою для україномовних науковців та дослідників. Вона надає українським науковцям можливість чіткіше зрозуміти найбільш ймовірні помилки, яких зазвичай припускає україномовний автор; а також висвітлює основні моменти щодо уникнення цих помилок.

У наукових дослідженнях мова неангломовних авторів повинна бути зрозумілою та переконливою. Для того щоб результати досліджень були доступні для інших фахівців і мали потенційний вплив на наукову спільноту, наукові дослідження повинні бути чітко викладені та подані у статті. Перешкодами для ефективного написання статті англійською мовою є відсутність досвіду у використанні наукової лексики та необізнаність із вимогами наукового письма англійською мовою, відсутність впевненості у здатності до письма, а також страх перед невдачею.

Розуміння наукової мови та структури, що використовується для створення рецензованої публікації, безумовно, підвищить ймовірність того, що поданий рукопис призведе до успішної публікації.

Таких результатів можна досягти, дотримуючись кількох простих пропозицій щодо складання / створення продукту для подання до публікації. Використовуючи запропоновані рекомендації та намагаючись уникнути поширених помилок, можна досягти успіху навіть авторам-початківцям. Мета цієї роботи - запропонувати практичні пропозиції щодо успішного написання наукової статті англійською мовою для професійних журналів, що рецензуються. Написання наукової статті для подальшої міжнародної публікації може бути складним, але приємним завданням. Можливість досліджувати, зіставляти та взаємопов'язувати докази, а також надавати рецензований та якісний продукт може бути корисною. Наступні декілька пропозицій можуть допомогти спробувати відшліфувати та вдосконалити свій підхід до наукового письма англійською мовою.

Ключові слова: часи, наукова мова, наукове дослідження, наукове письмо, стаття. 